\title{
No reduction of alpha-tocopherol quinone by glutathione in rat liver microsomes
}

Citation for published version (APA):

van Haaften, R. I. M., Evelo, C. T. A., Haenen, G. R. M. M., \& Bast, A. (2001). No reduction of alphatocopherol quinone by glutathione in rat liver microsomes. Biochemical Pharmacology, 61, 715-719. https://doi.org/10.1016/S0006-2952(01)00545-7

Document status and date:

Published: 01/01/2001

DOI:

10.1016/S0006-2952(01)00545-7

Document Version:

Publisher's PDF, also known as Version of record

Document license:

Taverne

Please check the document version of this publication:

- A submitted manuscript is the version of the article upon submission and before peer-review. There can be important differences between the submitted version and the official published version of record.

People interested in the research are advised to contact the author for the final version of the publication, or visit the DOI to the publisher's website.

- The final author version and the galley proof are versions of the publication after peer review.

- The final published version features the final layout of the paper including the volume, issue and page numbers.

Link to publication

\footnotetext{
General rights rights.

- You may freely distribute the URL identifying the publication in the public portal. please follow below link for the End User Agreement:

www.umlib.nl/taverne-license

Take down policy

If you believe that this document breaches copyright please contact us at:

repository@maastrichtuniversity.nl

providing details and we will investigate your claim.
}

Copyright and moral rights for the publications made accessible in the public portal are retained by the authors and/or other copyright owners and it is a condition of accessing publications that users recognise and abide by the legal requirements associated with these

- Users may download and print one copy of any publication from the public portal for the purpose of private study or research.

- You may not further distribute the material or use it for any profit-making activity or commercial gain

If the publication is distributed under the terms of Article $25 \mathrm{fa}$ of the Dutch Copyright Act, indicated by the "Taverne" license above, 


\title{
No reduction of $\alpha$-tocopherol quinone by glutathione in rat liver microsomes
}

\author{
Rachel I.M. van Haaften*, Chris T.A. Evelo, Guido R.M.M. Haenen, Aalt Bast \\ Department of Pharmacology and Toxicology, Faculty of Medicine, Universiteit Maastricht, P.O. Box 616, 6200 MD Maastricht, The Netherlands
}

Received 30 March 2000; accepted 26 September 2000

\begin{abstract}
The cell membrane is protected against lipid peroxidation by endogenous antioxidants such as vitamin E ( $\alpha$-tocopherol). The oxidised form of $\alpha$-tocopherol ( $\alpha$-tocopherol quinone) does not have this antioxidant function. However, the literature indicates that $\alpha$-tocopherol quinone can be reduced to $\alpha$-tocopherol in vivo and thereby will add to the total antioxidant potential (Moore AN, Ingold KU. Free Radic Biol Med 1997;22:931-4). We found that GSH (reduced glutathione) did not mediate the reduction of $\alpha$-tocopherol quinone, either directly in solution or in rat liver microsomes fortified with $\alpha$-tocopherol quinone. This renders GSH a less likely candidate for $\alpha$-tocopherol quinone reduction in vivo. In addition, $\alpha$-tocopherol quinone did not enhance GSH-dependent protection against lipid peroxidation, either in control microsomes, or in vitamin E-extracted microsomes. Indeed, $\alpha$-tocopherol quinone blocked GSH-dependent protection against lipid peroxidation in vitamin E-extracted microsomes. This indicates that $\alpha$-tocopherol quinone can act as a pro-oxidant. (C) 2001 Elsevier Science Inc. All rights reserved.
\end{abstract}

Keywords: Lipid peroxidation; Vitamin E; $\alpha$-Tocopherol; $\alpha$-Tocopherol quinone; Glutathione; Pro-oxidant

\section{Introduction}

Reactive oxygen species (ROS) play an important role in diseases such as cancer and cardiovascular and pulmonary disorders. They are formed continuously, e.g. by the cytochrome P450 system located in the microsomes (endoplasmic reticulum) in hepatocytes. Like all biomembranes, microsomes are susceptible to damage by ROS. In particular, polyunsaturated fatty acids in the membrane are vulnerable to lipid peroxidation. These polyunsaturated fatty acids are protected against peroxidation by antioxidants such as $\alpha$-tocopherol and reduced glutathione (GSH). Lipid-soluble $\alpha$-tocopherol functions as a chain-breaking antioxidant. Radicals that are formed during lipid peroxidation may abstract a hydrogen atom from the $\mathrm{OH}$ moiety of $\alpha$-tocopherol. In this way, radicals in the lipid bilayer are made inactive and $\alpha$-tocopherol radicals are formed. The latter can be further oxidised to $\alpha$-tocopherol quinone, which does not function as an antioxidant because it lacks the $\mathrm{OH}$ 4149 .

*Corresponding author. Tel.: +31-43-388-1340; fax: +31-43-388-

E-mail address: r.vanhaaften@farmaco.unimaas.nl (R.I.M. Van Haaften). moiety [1,2]. Moore and Ingold have shown [3] that $\alpha$-tocopherol quinone is converted to $\alpha$-tocopherol in vivo. This implies that $\alpha$-tocopherol quinone may indirectly contribute to the antioxidant status in vivo.

GSH protects against lipid peroxidation in cooperation with vitamin $\mathrm{E}[1,2,4-7]$. It has been reported that $\alpha$-tocopherol is regenerated from the $\alpha$-tocopherol radical by a microsomal GSH-dependent free radical reductase (inset in Fig. 1) $[1,2,4,8]$. In the present study, the recycling of $\alpha$-tocopherol from $\alpha$-tocopherol quinone by GSH was examined both after direct interaction and under conditions where $\alpha$-tocopherol quinone was present in the liver microsomal membrane. Liver microsomes were chosen since: (a) they contain an important radical-producing system; (b) the $\alpha$-tocopherol content is high; and (c) once the $\alpha$-tocopherol has been oxidised, the lipophilic $\alpha$-tocopherol quinone is likely to be retained within the microsomes. Moreover, the microsomes contain a free radical reductase that converts the $\alpha$-tocopherol radical to $\alpha$-tocopherol at the expense of GSH $[1,2,4,8]$. Possibly this or another microsomal enzyme might be involved in a GSH-dependent reduction of $\alpha$-tocopherol quinone to $\alpha$-tocopherol. The effect of $\alpha$-tocopherol quinone on the protection by GSH against lipid peroxidation was also studied. 


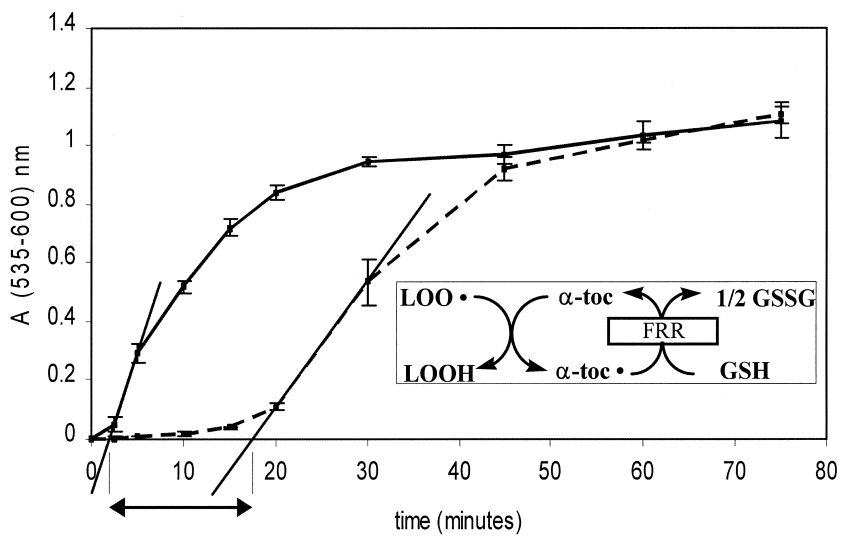

Fig. 1. Influence of GSH $(1 \mathrm{mM})$ on the time-course of lipid peroxidation in control microsomes with $(\cdots)$ and without (-) addition of GSH. Lipid peroxidation was induced by ascorbic acid $(0.2 \mathrm{mM})$ and $\mathrm{FeSO}_{4}(10 \mu \mathrm{M})$. Lag times, as given in Table 1, were determined as shown in the figure. Results are shown as the means $( \pm$ SEM) of three experiments. Inset: Interaction of $\alpha$-tocopherol ( $\alpha$-toc) and GSH in the protection against lipid peroxidation. The $\alpha$-tocopherol radicals ( $\alpha$-toc $)$ are regenerated to $\alpha$-tocopherol by GSH. This reaction is catalysed by a free radical reductase (FRR).

\section{Materials and methods}

\subsection{Chemicals}

GSH and $\alpha$-tocopherol quinone were obtained from ICN Biomedicals, and D- $\alpha$-tocopherol was obtained from Sigma. All other chemicals used were of analytical grade purity.

\subsection{Chemical reduction of $\alpha$-tocopherol quinone}

$\alpha$-Tocopherol quinone $(0.1 \mathrm{mM})$ was incubated with GSH $(0.1,1$, and $10 \mathrm{mM})$ at $25^{\circ}$ in potassium phosphate buffer $(10 \mathrm{mM}, \mathrm{pH} 7.4$, total volume $0.6 \mathrm{~mL})$. The change in the absorption spectra over time was monitored to study the reduction of $\alpha$-tocopherol quinone to $\alpha$-tocopherol.

\subsection{Microsomes}

Microsomes were prepared from male Lewis rats (CPV, Maastricht University, Maastricht, The Netherlands), 200$250 \mathrm{~g}$. After decapitation, the livers were removed and homogenised $(1: 2, \mathrm{w} / \mathrm{v})$ in ice-cold potassium phosphate buffer (50 mM, pH 7.4) containing $0.1 \mathrm{mM}$ EDTA. The homogenate was centrifuged at $10,000 \times g\left(20 \mathrm{~min}\right.$ at $\left.4^{\circ}\right)$. Subsequently, the supernatant was centrifuged at $10,000 \times$ $g\left(20 \mathrm{~min}\right.$ at $\left.4^{\circ}\right)$ and again at $65,000 \times g\left(60 \mathrm{~min}\right.$ at $\left.4^{\circ}\right)$. The microsomal pellet was resuspended in the phosphate buffer (2 $\mathrm{g}$ liver/mL) and stored at $-80^{\circ}$. Before use, the control microsomes were thawed and washed twice (centrifugation at $115,000 \times g, 40 \mathrm{~min})$ with ice-cold Tris- $\mathrm{HCl}$ buffer $(50$ $\mathrm{mM}, \mathrm{pH}$ 7.4) containing $150 \mathrm{mM} \mathrm{KCl}$.

$\alpha$-Tocopherol was extracted from the microsomes according to Maiorino et al. [9]. In short, the stored micro- somes were thawed and mixed with 2 volumes of ice-cold acetone and shaken vigorously. After $5 \mathrm{~min}$, the microsomes were washed twice with centrifugation at 115,000 $\times$ $g\left(40 \mathrm{~min}\right.$ at $\left.4^{\circ}\right)$. Care was taken to remove all the acetone, since it is known that acetone interferes with the method used to detect lipid peroxidation (i.e. acetone reacts with thiobarbituric acid). The pellet obtained after centrifugation of the microsomes was resuspended in ice-cold Tris- $\mathrm{HCl}$ buffer. $\alpha$-Tocopherol quinone was added to the microsomes after the extraction with acetone. The microsomes were mixed vigorously for $1 \mathrm{~min}$ and washed twice (centrifugation at $115,000 \times g, 40 \mathrm{~min}$ at $4^{\circ}$ ) with ice-cold Tris- $\mathrm{HCl}$ buffer.

\subsection{Reduction of $\alpha$-tocopherol quinone in microsomes}

$\alpha$-Tocopherol quinone $(0.55 \mu \mathrm{M}$ final concentration $)$ and an excess of GSH (1 mM final concentration) was added to microsomes (2 g liver/mL) and shaken vigorously. The microsomes were incubated by shaking (190 rpm, 37²), air being freely admitted, and the $\alpha$-tocopherol quinone and $\alpha$-tocopherol were determined using HPLC.

\subsection{Lipid peroxidation assay}

Microsomes (final concentration approximately $1 \mathrm{mg}$ protein $/ \mathrm{mL}$ ) were incubated at $37^{\circ}$ by shaking $(140 \mathrm{rpm})$, air being freely admitted, in Tris- $\mathrm{HCl} / \mathrm{KCl}(50 \mathrm{mM} / 150 \mathrm{mM}$, $\mathrm{pH}$ 7.4). Ascorbic acid (0.2 mM) and GSH (1 mM) were neutralised with $\mathrm{KOH}$ before addition. Reactions were started by adding a freshly prepared $\mathrm{FeSO}_{4}$ solution (10 $\mu \mathrm{M})$. Lipid peroxidation was assayed by measuring thiobarbituric acid (TBA)-reactive material [1]. Mixing with ice-cold TBA-trichloroacetic acid (TCA)-HCl-butylhydroxytoluene (BHT) solution $(2 \mathrm{~mL})$ stopped the reaction in an aliquot of the incubation mixture $(0.3 \mathrm{~mL})$. After heating $\left(15 \mathrm{~min}, 80^{\circ}\right)$ and centrifugation $(5 \mathrm{~min})$, the absorbance at 535 versus $600 \mathrm{~nm}$ was determined. The TBA-TCA-HCl solution was prepared by dissolving $1.68 \mathrm{~g}$ TCA and 41.6 mg TBA in $10 \mathrm{~mL} 0.125 \mathrm{M} \mathrm{HCl}$. BHT was dissolved in ethanol $(1.5 \mathrm{mg} / \mathrm{mL})$, and $1 \mathrm{~mL}$ of this solution was added to $10 \mathrm{~mL}$ TBA-TCA-HCl. The added chemicals did not interfere with the assay at the concentrations used.

\subsection{Determination of $\alpha$-tocopherol, $\alpha$-tocopherol quinone, and protein}

$\alpha$-Tocopherol and $\alpha$-tocopherol quinone were extracted from the membrane to determine the concentration in the microsomes. The extraction was performed by adding $1 \mathrm{~mL}$ of microsomes to $400 \mu \mathrm{L}$ water, $2 \mathrm{~mL}$ ethanol, $10 \mu \mathrm{L}$ internal standard ( $\alpha$-tocopherol nicotinate, $200 \mu \mathrm{g} / \mathrm{mL}$ ). After shaking for $5 \mathrm{~min}, 3 \mathrm{~mL}$ hexane was added and the mixture was shaken again (10 $\mathrm{min})$. The hexane layer was then evaporated and the residue was dissolved in $30 \mu \mathrm{L}$ isopropylalcohol. The different products were quantified 
using HPLC (Nucleosil 100-5 C18 column, Hewlett-Packard, eluted with $99 \%$ methanol; flow rate $2.0 \mathrm{~mL} / \mathrm{min}$ ) with diode array detection. $\alpha$-Tocopherol and the $\alpha$-tocopherol nicotinate were quantified using the absorption at $295 \mathrm{~nm}$, $\alpha$-tocopherol quinone using the absorption at $270 \mathrm{~nm}$. Microsomal protein was assayed according to Smith et al. [10], using BSA as standard.

\subsection{Measurement of GSH}

The stability of reduced GSH during the incubation was verified according to the method developed by Ellman [11] by adding 5,5'-dithiobis(2-nitrobenzoic) acid (DTNB, final concentration $0.6 \mathrm{mM}$ ) to $0.1 \mathrm{mM} \mathrm{GSH}$ solution incubated in potassium phosphate buffer (10 mM, pH 7.4) for up to 30 min. Incubations were performed with and without the addition of $0.1 \mathrm{mM} \alpha$-tocopherol quinone. The reaction of GSH with DTNB was allowed to proceed for $5 \mathrm{~min}$, after which the absorbance at $412 \mathrm{~nm}$ was determined. It should be noted that this assay only measures GSH and not GSSG, since glutathione reductase is not present.

\section{Results}

The possible reduction of $\alpha$-tocopherol quinone to $\alpha$-tocopherol by GSH was examined by adding different concentrations of GSH $(0.1,1$, and $10 \mathrm{mM})$ to an $\alpha$-tocopherol quinone solution $(0.1 \mathrm{mM})$ in buffer. The change in absorption spectra was examined to monitor the reaction. The $\alpha$-tocopherol quinone spectrum did not change within 30 min after addition of GSH, regardless of the GSH concentration, indicating that no reaction had occurred. Fig. 2 shows an example of such a spectrum (the interaction between $0.1 \mathrm{mM} \mathrm{GSH}$ and $0.1 \mathrm{mM} \alpha$-tocopherol quinone is depicted). In addition, no GSH consumption, measured by the non-enzymatic GSH assay, was observed during the 30-min incubation period, confirming that no reaction had indeed taken place. The strong reductant borohydride caused the reduction of $\alpha$-tocopherol quinone to $\alpha$-tocopherol hydroquinone, as is also observed in the change in the absorption spectrum. For comparison, the spectrum of $\alpha$-tocopherol was also depicted.

To further examine the interaction of oxidised $\alpha$-tocopherol with GSH, rat liver microsomes were loaded with $\alpha$-tocopherol quinone $(0.55 \mu \mathrm{M})$ and the GSH $(1 \mathrm{mM})$ induced formation of $\alpha$-tocopherol was monitored by HPLC (approximately 2000 times more GSH than $\alpha$-tocopherol quinone was present in the microsomes). The membrane concentrations of $\alpha$-tocopherol and $\alpha$-tocopherol quinone were not altered by addition of GSH to microsomes fortified with $\alpha$-tocopherol quinone. Next, the endogenous vitamin $\mathrm{E}$ was removed from the microsomes by acetone extraction. After extraction, the $\alpha$-tocopherol quinone concentration dropped from $0.23 \mathrm{nmol} \alpha$-tocopherol $/ \mathrm{mg}$ protein to below the lower limit of detection (i.e. $0.036 \mathrm{nmol} \alpha$-tocopher-

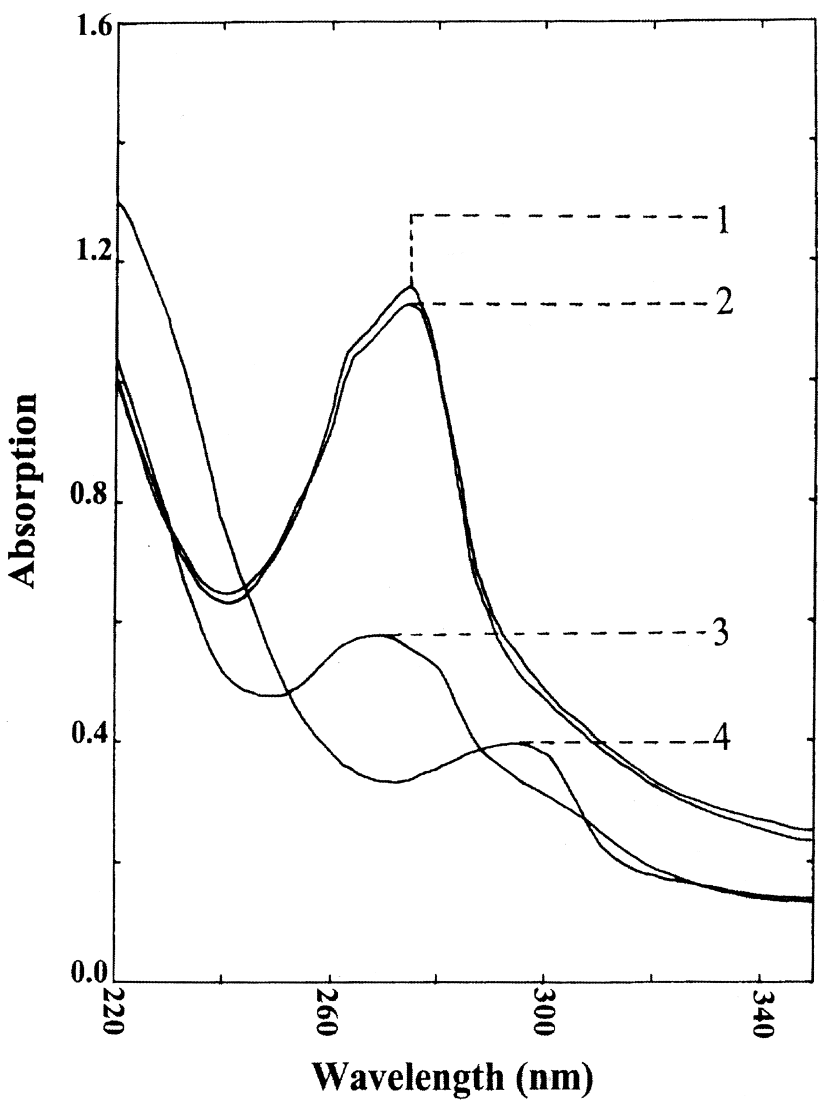

Fig. 2. The UV absorption spectra of an $\alpha$-tocopherol quinone solution $(0.1$ $\mathrm{mM})$ (blank: spectrum 1) with the addition of GSH $(0.1 \mathrm{mM})$ (spectrum 2) or $\mathrm{NaBH}_{4}$ (spectrum 3). Spectrum 2 was examined 30 min after the addition of GSH and spectrum 31 min after the addition of $\mathrm{NaBH}_{4}$. Spectrum 3 was depicted to show that a reduction in $\alpha$-tocopherol quinone is indeed possible. Spectrum 4 shows the absorption spectrum of $\alpha$-tocopherol.

$\mathrm{ol} / \mathrm{mg}$ protein). Lipid peroxidation and the effect of GSH on this process were examined in both these extracted microsomes (with or without the addition of $\alpha$-tocopherol quinone) and in control unextracted microsomes (with or without the addition of $\alpha$-tocopherol quinone). Reduction of $\alpha$-tocopherol quinone by GSH is expected to increase the protective effect of GSH against lipid peroxidation. We studied whether such increased protection really occurred.

The results are listed in Table 1. In Fig. 1, the timecourse of lipid peroxidation in control microsomes is depicted to explain how the lag times in Table 1 were obtained. Protection by $1 \mathrm{mM} \mathrm{GSH}$ against lipid peroxidation was clearly visible and resulted in a 14.3-min GSH-induced lag time in the control microsomes. In the extracted microsomes, protection against lipid peroxidation by GSH was reduced to $6.5 \mathrm{~min}$ compared to that in control microsomes. $\alpha$-Tocopherol quinone $(0.55 \mu \mathrm{M})$ addition alone had no effect on iron/ascorbate-induced lipid peroxidation. This again demonstrates that $\alpha$-tocopherol quinone has no antioxidant activity on its own. $\alpha$-Tocopherol quinone also had no effect on the GSH-dependent protection in control mi- 
Table 1

Lag time of microsomal lipid peroxidation induced by $1 \mathrm{mM} \mathrm{GSH}$

\begin{tabular}{|c|c|c|}
\hline & \multicolumn{2}{|c|}{ GSH-induced lag time (min) } \\
\hline & $\begin{array}{l}\text { Without } \alpha \text { - } \\
\text { tocopherol } \\
\text { quinone addition }\end{array}$ & $\begin{array}{l}\text { With } \alpha \text { - } \\
\text { tocopherol quinone } \\
(0.55 \mu \mathrm{M}) \text { addition }\end{array}$ \\
\hline Control microsomes & $14.3 \pm 0.4(\mathrm{~N}=7)$ & $15.0 \pm 0.2(\mathrm{~N}=5)$ \\
\hline $\begin{array}{l}\alpha \text {-Tocopherol extracted } \\
\text { microsomes }\end{array}$ & $6.5 \pm 1.0(\mathrm{~N}=6)$ & $0 \pm 0(\mathrm{~N}=4)$ \\
\hline
\end{tabular}

Lipid peroxidation was induced by $10 \mu \mathrm{M} \mathrm{Fe}^{2+}$ and $0.2 \mathrm{mM}$ ascorbate. The lag time induced by $1 \mathrm{mM}$ GSH was determined. Data are expressed as means \pm SEM of at least four experiments.

crosomes, whereas it completely blocked the GSH-dependent protection in the $\alpha$-tocopherol-extracted microsomes.

\section{Discussion}

$\alpha$-Tocopherol protects against lipid peroxidation. This protection is achieved via the scavenging of lipid peroxyl radicals by $\alpha$-tocopherol. The $\alpha$-tocopherol radicals thus formed can be regenerated in the membrane by cytosolic antioxidants such as vitamin C or GSH (inset in Fig. 1). Nevertheless, some of the $\alpha$-tocopherol radicals will not be captured by this recycling process and will be oxidised further to $\alpha$-tocopherol quinone, which has no antioxidant properties [1,2].

Moore and Ingold [3] have shown that $\alpha$-tocopherol quinone is reduced to $\alpha$-tocopherol in man. They concluded that $\alpha$-tocopherol quinone might function as an antioxidant precursor. GSH is one of the likely candidates to serve as the reductant for $\alpha$-tocopherol quinone [5]. However, we found no reduction in $\alpha$-tocopherol quinone by GSH either directly in solution or in fortified microsomes (Fig. 2). The presence of the cytochrome P-450 system in liver microsomes, which may serve as a potent source of free radicals, makes the $\alpha$-tocopherol present in these microsomes prone to oxidation. There are several indications that the $\alpha$-tocopherol radical, which is formed first, can be regenerated to $\alpha$-tocopherol by a free radical reductase that uses GSH for its reducing equivalents $[1,2,4,8]$. As shown in this study, once the $\alpha$-tocopherol had been oxidised to $\alpha$-tocopherol quinone, GSH was not capable of recycling this oxidised form of $\alpha$-tocopherol (Fig. 2). Apparently, the conversion of $\alpha$-tocopherol quinone to $\alpha$-tocopherol observed by Moore et al. [3] was not due to direct interaction or to a GSH-dependent reaction with $\alpha$-tocopherol quinone in liver microsomes. The results of the lipid peroxidation experiments confirm that there is no significant conversion of $\alpha$-tocopherol quinone to $\alpha$-tocopherol by GSH in liver microsomes. If GSH had converted $\alpha$-tocopherol quinone to $\alpha$-tocopherol, the addition of $\alpha$-tocopherol quinone to $\alpha$-tocopherol-extracted microsomes would have increased the GSH-dependent lag time.

GSH-dependent protection against lipid peroxidation was clearly observed in control microsomes (Table 1). A reduction in the $\alpha$-tocopherol level by extraction with acetone to a concentration below the limit of detection greatly reduced GSH-dependent protection against lipid peroxidation [12]. This was expected because GSH-dependent protection functions in part through reduction of the $\alpha$-tocopherol radical, and lowering of $\alpha$-tocopherol levels decreases the efficiency of the protection against radicals involved in lipid peroxidation $[1,4,6,13]$. $\alpha$-Tocopherol quinone did not affect GSH-dependent protection in microsomes that contained $\alpha$-tocopherol (control microsomes), but it did completely block GSH-dependent protection in $\alpha$-tocopheroldepleted microsomes. This implies that $\alpha$-tocopherol quinone can be toxic to lipid membranes of rat liver microsomes when the $\alpha$-tocopherol concentration is low. A possible explanation for this effect is that $\alpha$-tocopherol quinone competes with $\alpha$-tocopherol for binding to the microsomal labile free radical reductase, which catalyses the reaction as shown in the inset in Fig. 1. It has been demonstrated that this microsomal free radical reductase is not specific for $\alpha$-tocopherol and also interacts with $\alpha$-tocopherol-like components $[14,15]$. Thus, $\alpha$-tocopherol quinone might block the interaction of $\alpha$-tocopherol with this enzyme. In this way, $\alpha$-tocopherol quinone would function as an $\alpha$-tocopherol antagonist. However, such an antagonistic effect of $\alpha$-tocopherol quinone is only discerned when $\alpha$-tocopherol levels are very low.

It has been shown previously that GSH-dependent protection is drastically reduced in partly oxidised membranes $[1,2,12]$. One possible explanation for this reduction is the inactivation of the free radical reductase by intermediates formed during lipid peroxidation [2]. Vitamin E consumption and, as shown in this study, the formation of $\alpha$-tocopherol quinone may also contribute to the reduction of GSHdependent protection once the process of lipid peroxidation has started. The antagonistic effect of oxidised $\alpha$-tocopherol on GSH-dependent protection resembles that of oxidised glutathione, since this oxidised antioxidant also reduces GSH-dependent protection [5].

In conclusion, GSH is not able to regenerate $\alpha$-tocopherol in rat liver microsomes once it has been oxidised to $\alpha$-tocopherol quinone. This implies that there is no positive effect of $\alpha$-tocopherol quinone on GSH-dependent protection against microsomal lipid peroxidation. In contrast, when the $\alpha$-tocopherol concentration is low, $\alpha$-tocopherol quinone may even reduce GSH-dependent protection, and thus act as a pro-oxidant.

\section{References}

[1] Haenen GR, Bast A. Protection against lipid peroxidation by a microsomal glutathione-dependent labile factor. FEBS Lett 1983;159: $24-8$.

[2] Haenen GR, Tai Tin Tsoi JN, Vermeulen NP, Timmerman H, Bast A. 4-Hydroxy-2,3-trans-nonenal stimulates microsomal lipid peroxidation by reducing the glutathione-dependent protection. Arch Biochem Biophys 1987;259:449-56. 
[3] Moore AN, Ingold KU. $\alpha$-Tocopherol quinone is converted into vitamin E in man. Free Radic Biol Med 1997;22:931-4.

[4] Haenen GR, Bastiaans HM, Bast A. Mechanism of the glutathionedependent protection against microsomal lipid peroxidation. In: Yagi K, Kondo M, Niki E, Yoshikawa T, editors. Oxygen radicals. Amsterdam: Excerpta Medica, 1992. p. 731-6.

[5] Scholz RW, Reddy PV, Wynn MK, Graham KS, Liken AD, Gumpricht E, Reddy CC. Glutathione-dependent factors and inhibition of rat liver microsomal lipid peroxidation. Free Radic Biol Med 1997; 23:815-28.

[6] Reddy CC, Scholz RW, Thomas CE, Edward MM. Vitamin E dependent reduced glutathione inhibition of rat liver microsomal lipid peroxidation. Life Sci 1982;31:571-6.

[7] Burk RF. Glutathione-dependent protection by rat liver microsomal protein against lipid peroxidation. Biochem Biophys Acta 1983;757: $21-8$.

[8] McCay PB, Brueggemann G, Lai EK, Powell SR. Evidence that alpha-tocopherol functions cyclically to quench free radicals in hepatic microsomes. Ann N Y Acad Sci 1989;570:32-45.

[9] Maiorino M, Coassin M, Ursini F. In: Poli G, Cheeseman KM, Dianzani MU, Slater TF, editors. Advances in the biosciences. Oxford: Pergamon Press, 1989. p. 317-23.
[10] Smith PK, Krohn RI, Hermanson GT, Mallia AK, Gartner FH, Provenzano MD, Fujimoto EK, Goeke NM, Olson BJ, Klenck DC. Measurement of protein using bicinchoninic acid. Anal Biochem 1985; 150:76-85.

[11] Ellman GL. Tissue sulfhydryl groups. Arch Biochem Biophys 1959; 82:70-7.

[12] Bast A, Haenen GR. Regulation of lipid peroxidation by glutathione and lipoic acid: involvement of liver microsomal vitamin $\mathrm{E}$ free radical reductase. In: Emerit I, Packer L, Auclair C, editors. Antioxidants in therapy and preventive medicine. New York: Plenum, 1990. p. 111-6.

[13] Bast A, Haenen GR. Cytochrome P-450 and vitamin E free radical reductase: formation of and protection against free radicals. In: Crastes de Paulet A, Douste-Blazy L, Paoletti R, editors. Free radicals, lipoproteins and membrane lipids. New York: Plenum, 1990. p. 359-70.

[14] Aarts L, van der Hee R, Dekker I, de Jong J, Langemeijer H, Bast A. The widely used anesthetic agent propofol can replace $\alpha$-tocopherol as an antioxidant. FEBS Lett 1995;357:83-5.

[15] van Acker FA, Schouten O, Haenen GR, van der Vijgh WJ, Bast A. Flavonoids can replace $\alpha$-tocopherol as an antioxidant. FEBS Lett 2000;473:145-8. 